\title{
From the Street to the Village: The Transfer of NZ Youth Gang Culture to Sāmoa
}

\author{
Moses Ma'alo Faleolo
}

\begin{abstract}
A study of Sāmoan young people's associations with youth gangs in South Auckland found that the parents' practice of sending of troubled young people to extended family in Sāmoa, in the hope that the move would transform them into 'well-behaved' individuals, often falls short of expectations and may, in some cases, have the opposite effect. That study revealed that young people who had been repatriated had ideas about why this practice was often unsuccessful, and about measures which might improve outcomes.

Their insights were incorporated in a more formal model which is proposed in this article. Rather than depend on extended families in Sāmoa to carry out the 'transformation', a more formal, multi-faceted policy approach is recommended to improve the outcomes of this process. The policy advocated here calls for proactive engagement from the village leadership, and Sāmoan government support for the creation of, and training for, youth outreach activities such as mentoring, workforce development, education and training.
\end{abstract}

Keywords: Fa'asāmoa, youth gangs, socialisation, resocialisation, involuntary return migration, faleo'o model

\section{Introduction}

The transfer of youth gang culture from New Zealand to Sāmoa is a significant social issue and one that requires urgent attention. There are many reasons why some Sāmoan young people in New Zealand form or join gangs. For some young Sāmoans growing up in low income family households in povertystricken suburbs in New Zealand, gangs are seen as a means of escapism (Agnew, 2015). For others, a lack of adult supervision where parents are away working several jobs and excessive use of physical punishment in an attempt to instil discipline and conformity (Pardini, Waller \& Hawes, 2015) lead them to associate with gangs. While gangs also exert control over their members, through requiring strict adherence to a gang code or rules, unlike most Sāmoan families, gangs provide their members the freedom to express themselves and 
have their opinions listened to and taken seriously. Other Sāmoan young people, who do not trust or feel close to their parents or older siblings, turn to gangs to obtain guidance from older gang members and learn about sexual activity, alcohol and illicit drug consumption. In the gangs they are exposed by gang associates to criminal activities, high-risk health behaviour, and other antisocial practices.

Eventually their conduct attracts the attention of police, local authorities and social services and also negatively affects their families and their already challenging socio-economic situations. Faced with this situation, some Sāmoan families resort to sending their teenage children to Sāmoa to get them away from gang life. While the parents hoped their extended families in Sāmoa could persuade their teenage child to unlearn gang values, culture and activities and re-connect them with Sāmoan values, culture and language, this often did not eventuate. Instead, the 'deportees' used what they learned in their gang to adapt and adjust to authoritarian Sāmoan semi-rural, village life. They created gangs that replicated New Zealand ethnic minority gangs to build a reputation for themselves, for protection, and to allow them to continue the activities they were involved in New Zealand. Not long after they were sent to Sāmoa, frustrated extended family members, who struggled to manage their behaviour while they were in their care, often sent them back to New Zealand. This cycle often has negative outcomes for all of those involved: parents, their children and their families in Sāmoa.

My concerns arise from five life stories ${ }^{1}$ retrieved from young people in my doctoral study entitled, "Hard-Hard. Solid"! Life Histories of Sāmoans in Bloods Youth Gangs in New Zealand." The findings suggest that parents believe that sending young people back to Sāmoa is a way of addressing their young people's wayward behaviour (specifically disobedience to and disrespect for authority) by replacing values, beliefs and conduct learned in the gang with Sāmoan cultural values, beliefs and conduct. The starting point for this paper's research questions were: Why were parents sending their sons back to Sāmoa? Did spending time in Sāmoa reform their sons? How is it possible for gang culture to establish itself in Sāmoa? Is it time to consider a strategy to address the social issues reported in this study? This article turns first to theories of the

\footnotetext{
$1 \quad$ A total of twenty-five life stories were collected.

2 Most gang members ended their sentences with the term, "hard", to demonstrate how tough they were, or how they managed to get through difficult situations. If a gang member survived a series of tough and difficult situations he would use the term "solid" to indicate he was resilient and staunch and probably a long serving member with a higher ranking.
} 
processes of cultural socialisation, cultural re-socialisation, involuntary return migration and transnationalism. The paper then outlines the research method, the findings and discusses those findings. Finally, a recommendation, the faleo'o model, based on one of the young people's suggestions for addressing the social problem of youth gang culture in Sāmoa, is offered.

\section{Theoretical Framework}

Socialisation relates to how one learns from interacting with others in a variety of social situations, and by gradually developing the ability to take the role of the 'other'. A number of studies have explored human development and the life course to understand and clarify the socialisation process. Studies have analysed early childhood experiences to see how children's personality and psychology develop (Freud, 1923 \& 1961; Brenner, 1954 \& 1982; Fine, 1990; Elliot, 2002; Eagle, 2007). Others have analysed symbolic interactions and have highlighted a link between social structure (family, school, peer groups, the community) and behavioural development (Mead, 1934; Parsons, 1951 \& 1959; Blumer, 1969; Sheldon, 1980; Sheldon \& Vryan, 2003). Finally, studies in social learning theory, where the learning occurs from observing, imitating and modelling behaviour from other people (parents, school teachers, sports coaches, peers), is another approach to the study of the socialisation process (Miller \& Dollard, 1941; Bandura, 1977; Grusec, 1992; McAlister, Perry \& Parcel, 2008; Santrock, 2008).

A sub-set of socialisation studies focus on cultural socialisation. Cultural socialisation is the transmission from parents to children of information regarding cultural identity ('who I am'), cultural knowledge ('why I am different') and cultural practices ('how I act') (Phinney \& Chavira, 1995; Hughes \& Chen, 1999; Umaña-Taylor \& Fine, 2004; Hughes, Bachman, Ruble $\&$ Fuligni, 2006). The process is dependent on interaction with society members (symbolic interaction) and based on learning through observation, copying and modelling processes (social learning). At the heart of cultural socialisation is the role the family plays, particularly in identity formation (Phinney \& Rotheram, 1987; Knight \& Bernal, 1993; Knight, Bernal, Cota, Garza \& Ocampo, 1993) and in child rearing practices that include promoting pride, cultural knowledge, and cultural traditions (Hughes, Rodriguez, Smith, Johnson, Stevenson \& Spicer, 2006). Parents socialise their children in ways which are consistent with their cultural beliefs, behaviours, and socioeconomic 
situation (Zayas \& Solari, 1994) and often within a context of biculturalism ${ }^{3}$ where children experience enculturation into more than one culture: the dominant culture and the culture of their ethnic group (LaFrombois, Coleman, \& Gerton, 1993).

The transfer of the cultural complex called fa'aSāmoa from Sāmoan parents to their children in New Zealand is an example of cultural and family socialisation in a bicultural context in which the Sāmoan worldview and lifestyle co-exist alongside, and compete with, New Zealand ones. The reality is that variants of the dominant worldview and lifestyle often overwhelm the Samoan worldview and lifestyle in the enclave community, and parents become concerned at the apparent loss of Sāmoan culture and the values and practices which they consider the hallmarks of a socially mature individual. Sāmoan parents who send their young people back to Sāmoa, where the fa' aSämoa is the dominant culture, are hoping for some form of cultural re-socialisation. They hope, and indeed expect, that their children will experience re-enculturation into Sāmoan culture; re-learn their cultural identity, knowledge and practices and become respectful, humble, and obedient individuals who accept the roles expected of them in Samoan society.

Fa'aSāmoa is a complex reality. It is a set of beliefs about the Sāmoan way of life: it explains why Sāmoans think and act the way they do through etiquette and code (Faleolo, 2009 \& 2013; Mulitalo-Lauta, 2000). Meleisea (1988: 21) describes fa' aSämoa as a "socio-economic and political framework" based on the social structure of the aiga (family), the nu'u (village/polity) under the authority of the matai (chief), pulenu'u (village leader) and fono ole nu'u (village council). Others such as Tui Atua Tupua Tamasese elaborate on the psychological and emotive significance of fa'asāmoa and on how fa'asāmoa is for many Sāmoans their identity as it possesses a set of guidelines that dictate how Sāmoans should conduct their lives (Tui Atua Tupua Tamasese cited in Field, 1984). Lawson (1996) argues that fa'aSämoa is a concept linked closely with the ideals of culture and identity that not only define a certain group as a political entity, but also allows determined persons to claim set privileges within an established group. In this context, fa'aSāmoa is cemented in Sāmoan folklore, legends, phrases and proverbs, and in Sāmoan mythology, which provides a framework for social conduct in Sāmoan society. However, the impact of Christian missions in Samoa means that what is referred to as

3 This process is similar to multiculturalism where many cultures are enculturated (see Keller et. al., (2006)). 
fa' 'aSāmoa is also overlain and underpinned by Judaeo-Christian values, beliefs and symbols and these influences are often overlooked, or at least understated, in some of these definitions.

Transnationalism is where emigrants maintain multiple connections with their country of birth (Glick Schiller, Basch \& Szanton-Blanc, 1992; Mahler, 1998; Levitt \& Waters, 2002) by organising "their daily economic, familial, religious, and social relations within networks that extend across the borders of two nation-states" (Fouron \& Glick-Schiller, 2002, p.171). Many emigrant Sāmoans maintain complex active linkages with their country of birth and with specific communities within those nations. A feature of transnationalism, however, is the phenomenon known as 'return migration', where those who emigrate return temporarily or permanently to their homelands. Research outlines a range of reasons for these return movements. Gmelch (1980) identified three types of return migrants: those who intended to return after achieving predetermined goals set before they left; those who were forced to return because of external factors; and those who returned because of failure to adjust or homesickness. Thomas-Hope's (1985) research identified four other kinds of returnees or reasons for return migration: those who returned because of retirement or wanted to work back home; those who were dependents and left as children or were born overseas and returned to visit relatives or holiday; those who were students and returned after gaining qualifications; and those who travel back and forth re-entering the job market each time. A recent study (Macpherson and Macpherson 2009), highlighted a range of motivations that underlay the circulation of first and second generation New Zealand-born and Sāmoan-born youth between home and enclave communities. The authors found that because of the very different expectations and aspirations with which they arrived, young returnees had very different experiences of Sāmoa. However, until comparatively recently the literature had little to say on young people's return migration and particularly involuntary return migration (see Lee, 2003; Lee, 2004; Potter, 2005; Potter, Conway \& Phillips, 2005; Conway \& Potter, 2009; Lee, 2009; Lee \& Francis, 2009; Potter, Conway \& Bernard, 2009).

\section{Method}

A life story is the essence of what has happened to a person. In a life story interview, the interviewee is a storyteller, the narrator of the story being told, and the interviewer is simply a guide in this process. It is a narrative which includes the important events, experiences, and feelings in the lifetime of a 
person who provides it. It can provide the researcher with information about a social reality existing outside the story, described by the story (Bertaux, 1981), as well as about the story itself as a social construct (Rosenthal, 1993). It can provide in-depth insights which other methods overlook or fail to elicit (Plummer, 1983; Denzin \& Lincoln, 1994; Plummer, 1995; Gubrium \& Holstein, 1997) and offers comprehensive and concrete explanations (Denzin, 1989 \& 1992; Atkinson, 1998; Plummer, 2001; Roberts, 2002; Liamputtong, 2010).

The research collected twenty-five life stories from current Bloods gang members. These were Sāmoan males aged between sixteen and twenty-four years and living in various South Auckland suburbs in New Zealand. Sampling was purposive and snowballed as word-of-mouth persuaded more gang members to come forward with their stories. The interview schedule explored cultural, family and gang socialisation experiences in two sessions. The first session was spontaneous, unstructured and mostly led by the interviewee with some guidance by the interviewer. The interviewee was invited to talk about anything he felt was important in his life story to date. The second session was more focussed and interviewees were invited to think of their lives as books and to outline various chapters in their lives and to talk about critical events (low points, turning points, high points) within those chapters; major influences (person, group, organisation); culture (personal identity, beliefs and values), and strategies for preventing other Sāmoan young people from being attracted to gang culture.

Qualitative analysis software, QSR NVivo 10, was used to analyse of more than a hundred hours of digital audio recordings. This software generated a series of key themes one of which, involuntary return migration, is the subject of this paper. Whilst there are many strategies for qualitative data analysis, the researcher adopted a process outlined by Bryman (2008) and others (Charmaz, 2003; Ryan \& Bernard, 2003; Lofland, Snow, Anderson, \& Lofland, 2006). All transcripts were read twice: firstly as a whole during which notes were made about major themes, unusual issues, events, and principal categories. A second reading added marginal notes and annotations including memos, labels for codes, key words, combinations, groupings, connections between codes, researcher interpretation (relationships) and links to research questions and literatures. Codes, which indicated what chunks of text were about what themes, were indexed and related to the following questions: What is the person saying? What concepts do they use to understand their world? What meaning 
does it has for them? What linguistic typologies ${ }^{4}$ are used? What metaphors and analogies are shared?

\section{Findings and Discussion}

In this paper, five life stories which referred to involuntary return migration are outlined and explored. Four reasons highlighted in the findings, link concepts such as cultural and family re-socialisation and involuntary return migration and could possibly explain why, according to the boys, parents sent them back to Sāmoa.

Firstly, according to BPF, his parents attempted to change various aspects of his life because they were worried about his association with a Bloods gang (Red Army or RA).

"Like after 2006, that's when our name RA was like up there but I moved to the islands, I got sent there and they (the family) were trying to change me like my parents...yeah trying to change some parts in me." (BPF)

Secondly, TS's parents concern was around his schooling and safety.

"I was there nearly all of 2007, I got sent to Sāmoa like after the Christmas holidays, after the first two weeks at school I got kicked out cos I had a fight at school and that's when one of the other boys ended up in hospital, so my parents sent me to $\mathrm{Sa}^{5}$." (TS)

Thirdly, MS's parents felt their son had become too entrenched with the New Zealand way of life and sent him to Sāmoa to re-socialise him into fa'aSämoa.

"Once I left f------ work...that's when I went back to Sāmoa. I got sent back for three months just to remind me how the life over in Sāmoa was like." (MS)

Lastly, WF's parents' anxiety around their use of physical punishment, and on what they felt was failure on their part to correct his wayward behaviour, led them to seek another option rather than continuing with it.

$4 \quad$ Lexicons used within gangs to refer to specific gang activities.

5 Colloquial abbreviation of Sāmoa. 
"I was like getting a hiding a lot so my mom stopped giving me a hiding and just sent me to Sāmoa for six months..." (WF)

If the boys felt that these were the reasons why their parents sent them back to Sāmoa, then they could have been correct. BPF's thoughts about his mother's decision to send him to Sāmoa out of fear of bad external influences, and specifically his association with the Red Army was similar to what Lee (2003) found in her study of Tongan youth living in Australia who were being sent back to Tonga. She noted that Tongan families living overseas were also facing many problems, particularly their teenage children's ease of access to "smoking and alcohol consumption to petty criminal activity such as graffiti and shoplifting to more serious criminal behaviour that attracts police attention, including gang membership" (p.73). Lee (2004) also found that Tongan parents in Australia sent their children to Tonga to be re-socialised back into anga faka Tonga (the Tongan way). The goal of cultural re-socialisation reported by Lee for Tongans is similar to what BPF and MS thought their parents' reasons for sending them to Sāmoa.

When the boys arrived in Sāmoa, their parents were probably confident and relieved. In Sāmoa, their sons had a chance to complete schooling, to rebuild life, to spend time with extended family members and learn what it means to be a Sāmoan. Viewed in this way Sāmoan parents could have believed that the exposure should work because they had been brought up in Sāmoa and they had 'turned out okay'. However, the findings showed that the boys' experiences of Sāmoan village life varied and differed from their parents' expectations of how this exposure would reform their sons.

For BPF, the effects of being sent to Sāmoa were significant: he was separated, isolated and distanced from his mom, to whom he was very close, and his life in South Auckland, which was all he knew to that point. The experience made him feel "abandoned" and "disowned".

"I wanted to come back [to New Zealand] but she said 'no'...she started crying hard out. But I was crying too and I was saying 'ah yeah, all goods all the time'...I felt like I was abandoned or disowned or yeah far like she didn't want me." (BPF)

MS had to re-adjust and re-adapt to Sāmoan life after a twelve year absence from the country in which he was born and raised. 
“...went back to Sāmoa. That first week was alright. The second week I missed my parents and I missed the NZ life like how you wake up in the morning and you see the tray of eggs up there, then eat weetbix you know, have breakfast. When you want fizzy ${ }^{6}$, it's in the fridge you know. Sāmoa you open the fridge and that's right there is no fridge (laughs)..." (MS)

WF got "jumped" (assaulted) on his first day in Sāmoa.

"My first day I got jumped over there. Ah I was walking back to the village and then these Vaimoso guys they go, "polo o lou tamä"7 then I said, "Eā? sau ta pigi" ${ }^{8}$. F--k, one of them just ran over so I knocked him down to the ground..." (WF)

The boys' experiences of Sāmoan life contrasted with their parents' expectations in other ways. For instance, experiences of schooling and education in Sāmoa were no different than those in South Auckland except for the school curriculum. The curriculum in Sāmoa is behind New Zealand as BPF noted:

"Bro, I was like youse fellas need an upgrade. Youse can't be living with this stuff bro, this is like form 2 dude, cos like year 13 work over there is like form 2[in New Zealand]...F--k bro, when I went there I did everything. I [skulled it] ${ }^{9}$ back like nothing, every English, Maths, sole it was nothing bro..." (BPF)

The relationship the boys had with their teachers and fellow students in Sāmoa was hostile. In WF's case, he was assaulted on his first day in a Sāmoan school.

"Hmm, my first day at school um I was just sitting down and then the teacher just went, 'Na o lou nofonofo ina lou $k$--- (extreme obscenity) ae le fai mai se tala, ${ }^{10}$ Then I started swearing at him and then the teacher slapped me and told me to go and see the principal, at the principal's office he gave me a slap too when I told him what happened. So I just said, 'a f--k off' (laughs)...” (WF)

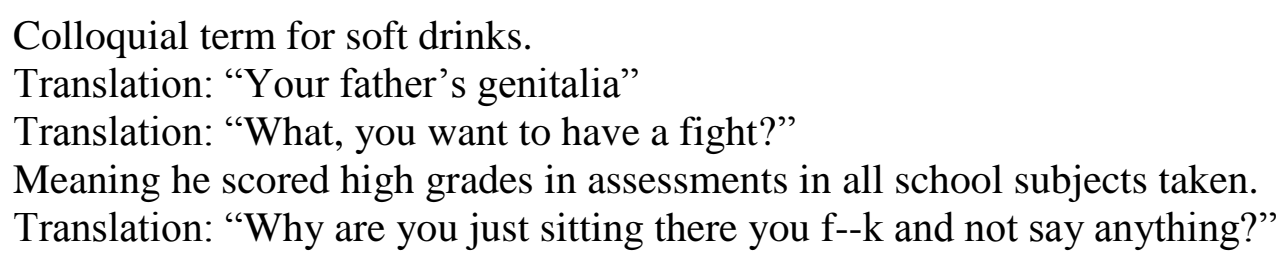


All the boys sent to Sāmoa by their parents were bullied in Sāmoan schools. BPF was bullied, until the bullies found out he was related to the principal and stopped.

"...I used to get like, the first three weeks of school; I used to get like bullied. I got bullied and all the kids used to bully me. But then once they found out that that my aunty was the principal they stopped. But like when they stopped the older kids kept bullying me but like [slyones] ${ }^{11}$, they used to tell me to like their buy their food or give them some money like twenty cents a day, which is like a dollar or two dollars to them..." (BPF)

While BPF was bullied for money and made to do things for the older students at his school, another returnee, TS, was bullied because of his appearance and specifically his "long hair."

"They sent me back to Apia. I went to school there and got kicked out for fighting. It was just them aye, they were jealous, especially how I had long hair...the first day I rocked in with my $a v a^{12}$ (laughs) and I got sent home. The school told me I had to go sele my $a v a^{13}$ and when I went back everyone's like this and that, 'Rasta-rasta-rasta this rasta that blah-blah-blah'." (TS)

LOP's experiences of being bullied were similar to those of BPF, over money, but LOP did not have an aunty who was the school principal at his school, so he confronted his bullies by accepting their challenge to a fight.

"...all these Sāmoans were like, 'sole sau"14 and I turned around. I was like nah going to class and I knew that you get stepped out a lot from the big guys in that school in Sāmoa, they are like old men. They kept calling me, 'Sole sau', and I turned around and walked down, and said, 'what's up', and then he collared me, you know, and said, 'E iai sau tupe?' ${ }^{\prime 5}$, and I said to him, 'sole, f--k you.' Then one of them in

\footnotetext{
11 Secretly or without anyone seeing him being bullied

12 Translation: Beard or facial hair

13 Translation: "Shave my beard"

14 Translation: "Hey you, come here"

15 Translation: "Have you got any money?"
} 
an angry voice yells, 'fia ulavale?'16 So I replied, 'Ioe, ou te fia ulavale $^{, 17}$ (laughs)..."

In the end, the boys' strategies for coping with experience of bullying in Sāmoan schools was led by the adage, 'if you can't beat them join them'. This is what BPF and LOP did.

“...they treated me good and then that's when I started like drinking with them. But like I never went to school I used to like change my uniform to plain clothes and then bus back to town and just look for them and then start drinking. Drink-drink goes home and lies to my aunty..." (BPF)

"...over time they started liking me cos I had a $\mathrm{fusu}^{18}$ at Apia, and then they started hanging around me. We started being [tight ${ }^{19}$ and I started getting famous (laughs) at school and plus we were [crumpers] $^{20}$. This siva ${ }^{21}$ was on yeah like crumping and I was a crumper and they all liked me cos of that too..." (LOP)

In addition to the 'join them' strategy, the boys replicated aspects of their lifestyle in South Auckland in Sāmoa. LOP's account his coping strategy in Sāmoa is reminiscent of his life in South Auckland where his alcohol-fuelled nights led to fights with rival gangs and to getting arrested. Only in Sāmoa, rather than Bloods versus Crip gangs, it was his school versus other schools; or him versus the stall owners in Apia markets.

"...this other time we got drunk as with these Year 13 boys...Afterwards, I got dropped off in Apia...we had a fusu bro, a mean fight, yeah man, with Avele ${ }^{22}$, half of Avele Boys and..."

"...I had fights with stall owners at the market...I was too drunk, but she was not like an old lady, she was a tom-boy, cut hair, all tats ${ }^{23}$, then she said "sau sau" 24 and I just went boom $(p a)^{25}$, she was

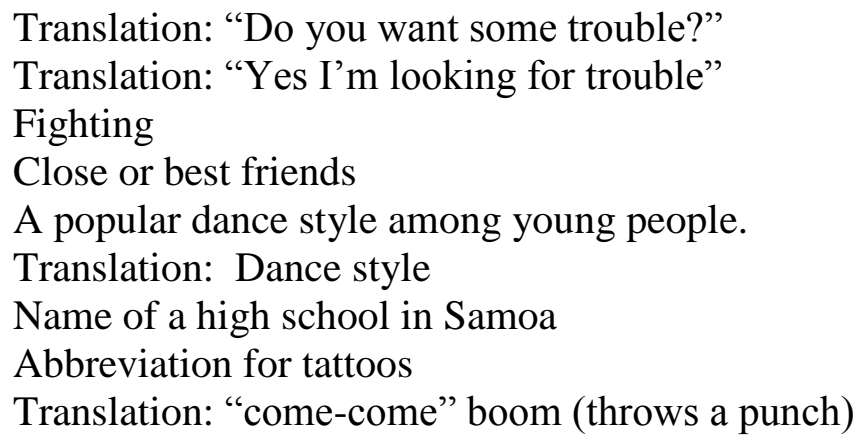


niniva $^{26}$ and fell back, and I just laughed. But then I got locked up for two months, and got bailed..."

MS transferred his knowledge of slanging, or selling marijuana, from South Auckland to Sāmoa and recruited boys from his village to form a gang.

MS: "See I started slanging ${ }^{27}$ in Sāmoa...the same style over here (New Zealand). I was trying to put it up in Sāmoa at my village (laughs). I was trying to put up a gang in my village yeah like my own crew..."

Interviewer: "Did you get a Bloods gang together over there?"

MS: "Ah yeah-yeah-yeah it was on, but we don't really have beef ${ }^{28}$ cos there are no Crips over there. I wanted to make the same life that was in NZ over there, like met up with the boys, stoned, kick back and talk just to keep me you know, "cos I miss the boys over here"

Eventually, the parents' confidence that the sending of their sons to Sāmoa would keep them out of trouble and help them, turned to concern and anxiety after family members who were looking after them reported that their sons' behaviour had not changed in Sāmoa. The boys were enrolled in Sāmoan schools but did not embrace or complete their education. They rebuilt their lives, but these new lives were copied from their lives in South Auckland. They did spend time with extended family members but some of their actions, like not going to school and spending time in Apia, and not listening to older extended family members who were trying to help them to change their behaviour, caused a strain in family relationships, and even brought them humiliation. What they learned about being a Sāmoan in Sāmoa is that it is no different from being a Sāmoan in South Auckland. They took what got them into trouble in New Zealand to Sāmoa, from the street to the village and in the process transferred youth gang culture from New Zealand to Sāmoa. As Lee noted in her study of Tongan youth returnees:

25 The sound of a punch making contact with a person's face

26 Translation: word for dizzy

$27 \quad$ Gang terminology for selling drugs

28 Issues or problems 
"Often the young people who are returned have already been in trouble overseas, and their presence in Tonga is creating considerable concern. Part of their impact appears to have been the transnationalisation of youth gangs..." (2004, p. 249)

The experiences of Sāmoan life for the boys showed that the practice of sending them back to Sāmoa for reform did not seem to have the desired outcome. This is highlighted in the boys' experience with school life in Sāmoa which was no different to New Zealand. Had BPF encountered a curriculum in Sāmoa that matched New Zealand, then the opportunity and incentive for him to complete his education would have been higher. It might have instilled confidence in him and provided him with a clear idea of what career prospects lay ahead. Instead he "skulled it back": it was easy for him to understand because of his New Zealand educational background that he was not challenged and perhaps complacency set in, making his educational experience meaningless.

Similarly, had WF encountered a teacher that understood him, who knew how to teach him, and to turn his weaknesses into strengths he might have also had an opportunity and incentive to complete his education. Instead, on his first day at school he is confronted by a teacher who WF felt was negative toward him in class and a principal who slapped him when WF tried to explain that it was the teacher that had provoked him into being disrespectful and react by using profanity.

To adapt and cope with their new environment and experiences such as schooling life, in Sāmoa the boys employed a 'replication strategy'. They reproduced in Sāmoa the things they did with their lives in New Zealand which had caused concern for their parents and subsequently got them sent to Sāmoa in the first place. For example, LOP befriended his bullies and then he embraced their lifestyle - which involved drinking, fighting, getting arrested, and later still, he started controlling and leading them. Another example was MS who introduced "slanging" to the boys in his village, and then recruited them to act as Bloods gang members, just like how he had started his gang back in South Auckland. LOP and MS not only brought the New Zealand gang culture to the school and village in Sāmoa but, more significantly, they passed on a lifestyle to other Sāmoan young people that was controversial in the eyes of some but perhaps necessary in their eyes in order to transition from the old life in New Zealand to a new life in Sāmoa. 
However, even more interesting is the fact that both LOP and MS were born in Sāmoa and spent the first ten years of their lives in Sāmoa before accompanying their parents and migrate to New Zealand for better opportunities. Because they had lived in New Zealand for some years, both would have had to find a way to fit-in to the New Zealand way of life including its school and neighbourhood subcultures by copying what their friends or family members were doing. Ten years later both boys found themselves being sent back to Sāmoa where they had to go through another social learning process to transition from life in New Zealand to life in Sāmoa. As a consequence, the transfer of youth gang culture in New Zealand to Sāmoa eventuated and the boys were the conduits that enabled this process.

In the end, their Sāmoan experience did not change the boys: they were still wayward and unruly. Given a chance, they would not have hesitated to return to South Auckland but they adjusted and settled into life in Sāmoa because they had no choice. Despite attempts by extended family members to transform the life the boys had in South Auckland through enrolling them in school, reintroducing church into their lives, and providing guidance and counsel, at the end of the day, their efforts fell short of culturally re-socializing the boys. As MS's grandparents discovered:

“...they ring and my grandparents go, 'It's better for you to bring him back he's getting worse over here and we don't want him to get $f^{\prime}$ 'asala $^{29}$ from the $n u^{\prime} u^{30}$. They were worried how I was getting drunk most times, shouting out choo-hoo, making noises and swearing, then they will have to pay the $s a a^{31}$ in the $n u^{\prime} u$ like a pusa $a p a^{32}$ and things like that..." (MS)

In the end, the boys felt that being sent back to Sāmoa had only made them worse and added further problems in their lives. For example, LOP commented:

"Eighteen I got sent to Sāmoa. Bro it was worse, it was worse man, you know they send you bro its making them worse, like I've been through it..." (LOP)

29 Translation: to be punished or fined by village leadership.

30 Translation: village or, more specifically in this case, the village leadership.

31 Translation: penalty levied by village councils on families of miscreants.

32 Translation: Box of cans - a reference to boxes of tinned food. 
For WF, being sent to Sāmoa only increased his problems, and his life in Sāmoa was no different from the life he left behind in South Auckland.

“It doesn't work. Perhaps for some people aye, but not me. Somehow I still came back the same, no changes (laughs). I was sent there because I was getting into trouble a lot over here, but somehow being sent to Sāmoa got me into more trouble; just different country, different bloody idiots." (WF)

Finally, the boys were sent back to South Auckland much to their relief and excitement which was short-lived. The outcomes since their return to New Zealand point to some of the problems of the repatriation and re-socialisation strategies adopted by their parents. Parents right away tried to contain them and the boys took some time to transition back into the New Zealand way of life. It was not long, however, before they drifted back into gang life and crime. Only BPF is attending a Tourism and Hospitality course in Auckland city but he is also currently on bail after being charged with theft and is awaiting trial on further charges, 'threatening to kill', after he and the RA gang gate crashed a party and assaulted a rival gang member after he was accidentally run over by his older brother.

"Ah, my mate Jekker used to text me come around let's drink and we used to drink at his house and then drink-drink there and at the end there was trouble, got done for theft and threatening to kill - f--k!" (BPF)

TS and WF are serving home detention sentences for aggravated robberies; both are wearing ankle bracelets and reside with their families. TS, LOP and MS became fathers not long after they returned from Sāmoa but still associate with the RA gang.

“...straight away, I got back with my missus again and that's when, you know, boom-boom-boom, action - maua le pepe. ${ }^{33 \text { " }}$ (LOP)

All the boys except BPF are still unemployed and under strict curfew. Their police records and lack of school qualifications remain obstacles entry into the labour market and to turning their lives around. So although the

33 Reference to unprotected sex leading to pregnancy and unanticipated fatherhood. 
practice of sending them to Sāmoa came to nothing, the same can also be said when they returned to New Zealand, the whole situation had come full circle.

\section{Toward a policy strategy}

The transfer of youth gang culture from New Zealand to Sāmoa is a significant issue for Sāmoa, and the practice of sending boys back to Sāmoa for reform is one vehicle for this. Gang culture impacts every dimension of Sāmoan society to which they are sent: social, economic, political, cultural and religious. Socially, gang culture creates strain on extended families particularly when dealing with the shame that follows the commission of crime by one of their members. Economically, gang culture incurs costs on the family including court, hospital or clinic, counselling and social service fees as well as village costs in the form of fines, societal costs such as operational and management overheads, and government pay outs like funding and resourcing of anti-gang programs. Politically, gang culture exposes the vulnerability of existing policies and highlights the need for new policy developments. Culturally, gang lifestyle offers an alternative identity for young village Sāmoans and an alternative culture to fa'aSämoa. Morally, it redefines 'right' and 'wrong' and blurs distinctions between right from wrong.

A solution raised by one of the gang members to address this issue starts with the Sāmoan village ${ }^{34}$. The faleo 'o ${ }^{35}$ model is proposed as a possible solution for addressing the issue of youth gang culture transference in Sāmoa. The faleo'o model works by placing the onus of responsibility on key village institutions to monitor, educate, correct, transform and rehabilitate Sāmoan young people who have been sent by their parents in New Zealand to the village because they have become wayward. It involves the pulenu' $u^{36}$, the 'aumaga ${ }^{37}$, and the taulele ${ }^{38}{ }^{38}$ because these institutions will have most direct contact with

\footnotetext{
$34 \quad$ A typical Sāmoan village will have bylaws which are also decided by representatives of its members. Particular members are appointed to carry out tasks to ensure the village operates in an orderly way.

The term faleo'o refers to one of the important structures in a typical Samoan village setting where meetings, discussions, decisions, planning and outcomes are agreed upon and forecasted. The usage of this term is not related to the architecture but focuses on what happens inside this structure and the processes that unfold throughout.

36 The pulenu' $u$ is a person who has been appointed to oversee the affairs of the village. This person is invariably a matai (chief) and usually an ali' $i$ (paramount chief).

37 The 'aumaga is a group of taule'ale'a, or untitled young men, who serve their families and the council of chiefs.

38 The taule'ale' $a$ is responsible for many tasks and duties that contribute to the well being of the village. Their responsibilities are vast: taking care of the elderly, parents, and
} 
those who have been sent to their village and thus have a stronger chance of influencing and imposing positive changes in conduct.

The faleo' $o$ model might work in the following way. Parents in New Zealand notify extended family members in Sāmoa that they are sending a son and by the time he arrives the pulenu' $u$ and 'aumaga are already aware and waiting. As soon as the son arrives in the village he is placed with the 'aumaga and allocated a taule'ale' $a$ as a buddy. He will not stay with his extended family but may visit or spend a night with them. The taule'ale'a teaches him what he has been taught and activates the process of correcting and reforming. He will learn things like the aganu' $u^{39}$ such as who he is, who his family members are, his ancestral lineage, the importance of respecting people, obedience, humility, and love. The taule'ale'a will be asked to suppress any talk, behaviour, or signs of youth gang culture like clothing and hand gestures through discipline and continuous demonstration of how a taule'ale'a lives his life in a Sāmoan village. As MS pointed out:

“...put them into the taulele' $a$ to learn how they do the galuega ${ }^{40}$ for the matai $^{41}$. You can put them in there cos it's the right age and they won't try and bring their gang thing in there. If they do one of the other taule'ale' $a$ will just stand up and ask him to be quiet, and say something like we don't need that (referring to gang behaviour) in here because this villages is for the Sāmoan culture not the gang... So he won't even say anything about Bloods or anything in there. He's just gonna be quiet and do what they say." (MS)

As a last resort, the taule'ale'a, if he chooses, could refer any noncompliance to the pulenu' $u$ to be dealt with through intervention in the returnee's family. In these situations, the pulenu' $u$ can impose a penalty payable in money, or food (such as barrels of corned beef) or fine mats ('ie toga), on the returnee's extended family in the village. The extended family would then

\footnotetext{
siblings - related and non-related; the plantation and tilling of the land for food and crops; prepare food and host guests; look after equipment for fishing, building and decor; and serve matai(s) without question. The taule 'ale' $a$ is the first to awaken and the last to sleep. They also patrol and ensure that village security is maintained while families are conducting their evening devotions. It is not uncommon for taule 'ale' $a$ to be employed as well in roles such as police officer, principals, and other professions. After some time a taule'ale'a may progress to matai status.

39 The term for customs, values, beliefs, protocols and spiritual guidance.

40 Translation: tasks, duties, or jobs.

41 Translation: chief or person in authority.
} 
contact family in New Zealand to honour the sala or penalty to maintain the returnee's family's reputation and, in extreme cases, to prevent them from being expelled from the village for a returnee's transgressions. As MS outlines below:

“...if the gang member get sala from the $n u$ ' $u$ like if he gets thinged [fined] from the village, his family have to provide ten boxes of tinned fish. And if he soli le tulafono ${ }^{42}$, his parents will have to send whatever money, but if they don't pay...then they'll be wiped away from that village and not allowed back..." (MS)

By placing the responsibility for correcting wayward young people in the hands of the taulele'a, 'aumaga and pulenu'u, the faleo'o model offers many advantages. At the individual level, re-socialising young people to think and behave like a village Sāmoan (which is predominantly about etiquette, and respecting others to gain their respect). It can build strong character, improve relationship building interactions, and enhance positive attitudinal traits (like patience, forgiveness, and resiliency). The returnee will be doing this by learning from the taule'ale' $a$ assigned to him and from the 'aumaga and matai.

At the village level, it minimises strain on extended families because they are supported by the village with the monitoring and re-socialisation, rather than going it alone and keeping their struggles to themselves because of shame. With buy-in from the village and the assignment of a taule'ale' $a$, the returnee's resentment at being forced to live in Sāmoa reduces as the need to be part of a group shifts from the gang to the 'aumaga.

The faleo'o model is thus a form of collective social responsibility involving extended families, pulenu'u, 'aumaga and taulele' $a$, which provides returnees with a more deliberate and coordinated re-socialisation and reform process, and involves earning respect through unconditional service to the 'aumaga, and, in time possibly, a matai title and associated status. The attainment of a matai title may be a bonus for parents in New Zealand whose primary objective for sending their son to Sāmoa was to transform him into a respectable Sāmoan adult and citizen.

At the Sāmoan government level, the faleo'o model could possibly be an additional policy initiative for Ministry of Women, Community and Social Development's (MWCSD) Division for Youth and the Sāmoa National Youth Council (SNYC). The re-establishment of the Sāmoa National Youth Council,

42 Translation: breaks village bylaws. 
which is funded by Australian Agency for International Development (AusAID) Pacific Leadership Program, aims to mobilize responsible youth citizenship to lead and help with the implementation of youth development projects and programs. Sāmoan young people who represent their district and then achieve election on the SNYC could further signal concerns (if necessary) on the practice of involuntary return migration or "deportation" and limit any emergence of social disruption within Sāmoan villages and particularly the spread of juvenile delinquency among its local youth population. So as a national platform that is coordinating the voice and concerns of Sàmoan young people, in contributing to Sāmoa's youth development policies the faleo'o model may be a consideration (see Australian Department of Foreign Affairs, 2014).

At the same time, extended family members and their villages require support to reform these young people sent to them. This might take the form of education and training for those who will become involved in different ways in any such programme. For example, they may or may not know the importance of understanding the role that transitional challenges play when one is moving from childhood to adolescence because it involves extensive physical, sexual, mental, and social changes. Some Sāmoan young people struggle to cope with these pubertal and hormonal changes and gangs provide a comfortable environment where its members are reassured to accept these changes as normal. If this is the case for returnees then extended family members and their village in Sāmoa are not going to be successful in removing their attraction to gangs especially if their approach focuses on discipline and punishment alone. Instead an awareness of understanding youth development would be an advantage toward improving how they would support wayward young people because this approach would be less authoritarian and more collaborative and sensitive.

There is a need for the Sāmoan government to review and re-think existing policies and perhaps consider the relevancy and appropriateness of the faleo'o model as a starting point for new policy development in this area. If nothing is done about supporting extended family members and village leaders the influence of gang values and practices in Sāmoan villages will continue to grow manifest and some of its own local Sāmoan youth could organize themselves into gangs with negative agendas drawn from transnational gang cultures, and become a disruptive force throughout Sāmoa. The increasing influence of gangs in Sāmoa that is currently being cultivated and catalysed by 
New Zealand-born Sāmoan youth carries with it the potential for increases in expenditures in health, education, law and order, social development, economic and cultural spheres.

Any review of existing policies and or the introduction of new policy need to embody three considerations. Firstly, new policy must be comprehensive and holistic and fully resourced, to ensure it stays keep pace with future trends. For example, research is needed to establish more accurately the extent of the social problem identified and examined in this article and to plan further projects thereafter. Secondly, the policy should evaluate existing social services and identify any 'gaps' and pilot test new strategies like the faleo'o model to measure its effectiveness, responsiveness and appropriateness. Similarly, strategies like service provider training and workforce policy development initiatives such as establishing a mentoring service, which can focus on the socio-cultural development for returnees, where mentors undertake village visits and could complement the social and cultural development work that the faleo'o model provides. Workers or taulele'a providing mentoring would need to be qualified and accredited specialists, with a cultural competency background that relates to the principles of the faleo'o model and dovetails with the roles of the pulenu'u, 'aumaga, matai, and taulele'a. Lastly, the policy should also be based on a partnership between government and the village that is collaborative, integrative in that it adopts both what the village and government want as goals, and participatory in that the village and government are both conducting complementary activities in association. It is important that, efforts are made while these wayward youth are in Sāmoa to keep them from being taken from their extended family members and sent back to New Zealand otherwise these young people will never change and their attraction to gang culture will continue to be more important perhaps than being a Sāmoan.

\section{Conclusion}

Some Sāmoan parents are sending teenage children to Sāmoa because they have become unmanageable, but there are many barriers to the successful transformation of wayward teenage children into law-abiding and docile individuals in Sāmoa. In the cases outlined in this article, the time they spent in Sāmoa did not achieve what parents had hoped: the youth did not unlearn what they learned in gangs and they did not take on board the Sāmoan cultural values and beliefs such as respect and humility that they were taught by their extended 
family members especially. Instead they reproduced gangs and engaged in associated antisocial activity as a means of adapting to Sāmoan island life. These provided protection especially from being bullied in Sāmoan schools, popularity among young recruits who grew up in the village, and selfgratification.

It is time to consider a strategy to prevent the transfer of youth gang culture from New Zealand to Sāmoa. Failure to act upon this growing social concern for Sāmoa could be detrimental to its villages, community development, and sectors such as health, education, law and order, social development, religion, economy and cultural identity. If growth of gang culture is not addressed, the erosion of Sāmoan society could be at stake as a new generation of Sāmoan young people find the attractions of gang membership greater than those of being a proud Sāmoan. A strategy could ensure that extended family members, the village and social services in Sāmoa are equipped with the means to manage wayward behaviour and thinking, and to put something in place like a faleo'o model to act as a mechanism to impart effective, responsive and appropriate initiatives. The strategy outlined in the paragraphs above is probably too simplistic but it is a start and could provide a starting point for discussion and refinement.

\section{References:}

Agnew, R. (2015). General strain theory and delinquency. (in) M.D Krohn \& J. Lane (Ed.). The Handbook of Juvenile Delinquency and Juvenile Justice. West Sussex, UK: Wiley Blackwell. (pp. 239-256).

Atkinson, R. (1998). The life story interview. Thousand Oaks, CA: Sage.

Australian Department of Foreign Affairs (2014, August). Australian Agency for International Development (AusAID) Sāmoa Fact Sheet. Canberra, Author.

Bandura, A. (1977). Social Learning Theory. New York: General Learning Press.

Bertaux, D. (1981). Biography and society. Beverly Hills, CA: Sage.

Blumer, Herbert (1969). Symbolic Interactionism: Perspective and Method. Berkeley: University of California Press.

Brenner, C. (1954). An Elementary Textbook of Psychoanalysis. New York: Anchor Books.

Brenner, C. (1982). The mind in conflict. Madison, CT: International Universities Press.

Bryman, A. (Eds). (2008). Social Research Methods. Oxford: Oxford University.

Charmaz, K. (2003). Grounded Theory. (in) J.A. Smith (Eds). Qualitative Psychology: A practical guide to research methods. London: Sage. (pp. 81-110).

Conway, D. \& Potter, R.B. (2009). Return migration of the next generation: $21^{\text {st }}$ century transnational mobility. England: Ashgate.

Denzin, N.K. (1989). Interpretive Biography. London: Sage.

Denzin, N.K. (1992). Symbolic Interactionism and Cultural Studies: The politics of interpretation. Oxford: Blackwell.

Denzin, N.K. \& Lincoln, Y. (Eds.). (1994). The Handbook of Qualitative Research. London: Sage. 
Eagle, M.N. (2007). Psychoanalysis and its critics. Psychoanalytic Psychology, 24, 10-24

Elliott, A. (Eds.) (2002). Psychoanalytic Theory: An Introduction. London: Palgrave and Duke University Press.

Faleolo, M.M. (2009). Culturally valid social work education: A Sāmoan perspective. (in) C. Noble, M. Henrickson and I.Y. Han (Ed.). Social work education: Voices from the Asia Pacific. Victoria, Australia: The Vulgar Press. (pp. 149-172).

Faleolo, M.M. (2013). Cultural authentication in social work education: a balancing act. (in) C. Noble, M. Henrickson \& I.Y. Han (Eds.). Social work education: Voices from the Asia Pacific. Sydney, Australia: Sydney University Press. (pp. 105-132).

Field, M. J. (1984). Mau: Sāmoa's Struggle against New Zealand Oppression. Wellington, NZ: Reed.

Fine, R. (1990). The History of Psychoanalysis. Northvale: Jason Aronson.

Fouron, G. \& Glick-Schiller, N. (2002). The generation of identity: redefining the second generation within a transnational social field. (in) P. Levitt \& M. Waters (Eds). The changing face of home: the transnational lives of the second generation (pp. 168208). New York: Russell Sage Foundation.

Freud, S. (1923 \& 1961). The Ego and the Id (vol.19). (in) S. Freud (Ed.). The Standard Edition of the Complete Psychological Works of Sigmund Freud. New York: Macmillan. (pp. 12-63).

Glick Schiller, N., Basch, L. \& Szanton-Blanc, C. (1992). Towards a Transnational Perspective on Migration: Race, Class, Ethnicity and Nationalism Reconsidered. New York: New York Academy of Science.

Gmelch, G. (1980). Return migration. Annals, Review of Anthropology, 9, 135-159.

Grusec, J.E. (1992). Social Learning theory and Developmental Psychology. Developmental Psychology, 28 (5), 776-786.

Gubrium, J.F. \& Holstein, J.H. (1997). The New Language of Qualitative Method. Oxford: Oxford University Press.

Hughes, D. \& Chen, L. (1999). The nature of parents' race-related communications to children: A developmental perspective. (in) L. Balter \& C.S. Tamis-Lemonda (Eds.). Child psychology: A handbook of contemporary issues. Philadelphia: Psychology Press. (pp. 467-490).

Hughes, D., Bachman, M. Ruble, D. \& Fuligni, A. (2006). Tuned in or tuned out: Children's interpretations of parents' racial socialization messages. (in) L. Balter \& C. TamisLemonda ( $2^{\text {nd }}$ Ed.). Child psychology: A handbook of contemporary issues. Philadelphia: Psychology Press. (pp. 591-610).

Hughes, D., Rodriguez, J., Smith, E.P., Johnson, D.J., Stevenson, H.C. \& Spicer, P. (2006). Parents' Ethnic-Racial Socialization Practices: A Review of Research and Directions for Future Study. Developmental Psychology, 42 (5), 747-770.

Keller, H., Lamm, B., Abels, M., Yovsi, R., Borke, J., Jensen, H., Papligoura, Z., Holub, C., Lo, W., Tomiyama, A., Su, Y., Wang, Y., \& Chaudhary, N. (2006). Cultural models, socialization goals, and parenting ethnotheories: A multicultural analysis. Journal of cross-cultural psychology, 37 (2), 155-172.

Knight, G.P., \& Bernal, M.E. (1993). Ethnic Identity. Albany, NY: State University of New York Press.

Knight, G.P., Bernal, M.E., Cota, M.K., Garza, C.A., \& Ocampo, K.A. (1993). Family socialization and Mexican American identity and behavior. (in) G.P. Knight \& M.E. Bernal (Eds.). Ethnic Identity. Albany, NY: State University of New York Press. (pp. 536-552).

LaFromboise, T., Coleman, H., \& Gerton, J. (1993). "Psychological impact of biculturalism: Evidence and Theory." Psychological Bulletin, 114 (3), 395-412. 
Lawson, S. (1996). Tradition versus Democracy in the South Pacific. Melbourne: Cambridge University Press.

Lee, H.M. (2003). Tongans Overseas: Between Two Shores. Honolulu: University of Hawaii Press.

Lee, H. (2004). Second generation Tongan transnationalism: Hope for the future? Asia Pacific Viewpoint, 45 (2), 235-254.

Lee, H. (2009). The ambivalence of return: Second-generation Tongan returnees. (in) D. Conway and R.B. Potter (Eds.). Return migration of the next generations: Twentyfirst century transnational mobility. Aldershot: Ashgate. (pp. 41-58).

Lee, H. \& Francis, S.T. (Eds.). (2009). Migration and Transnationalism Pacific Perspectives. Canberra: Australian National University Press.

Levitt, P. \& Waters, M. (2002). The changing face of home: the transnational lives of the second generation. New York: Russell Sage Foundation.

Liamputtong, P. (Eds.). (2010). Qualitative Research Methods. Oxford: Oxford University Press.

Lofland, J., Snow, D., Anderson, L., \& Lofland, L.H. (2006). Analyzing social settings: A guide to Qualitative Observation and Analysis. Belmont, CA: Wadsworth and Thomson.

Macpherson, C., \& Macpherson, L. (2009). It was not quite what I had expected: Some Sāmoan returnees' experiences of Sāmoa. (in) D. Conway and R.B. Potter (Eds.). Return Migration of the Next Generations: $21^{\text {st }}$ Century Transnational Mobility. Aldershot: Ashgate. (pp. 19-39).

McAlister, A.L., Perry, C.L., \& Parcel, G.S. (2008). How Individuals, Environments, and Health Behaviors Interact: Social Cognitive Theory. (in) K. Glanz, B.K. Rimer and K.Viswanath (4 ${ }^{\text {th }}$ Ed.). Health Behavior and Health Education: Theory, Research, and Practice. San Francisco, CA: John Wiley \& Sons. (pp. 169-188).

Mahler, S. (1998). Theoretical and Empirical Contributions: Toward a Research Agenda for Transnationalism. (in) M. Smith \& L. Guarnizo (Eds.). Transnationalism from Below. New Brunswick: Transaction Publishers. (pp. 64-100).

Mead, G.H. (1934). Mind, Self and Society. Chicago: University of Chicago Press.

Meleisea, M. (1988). Change and adaptation in Western Sāmoa. Christchurch: Macmillan Brown Centre for Pacific Studies, University of Canterbury.

Miller, N. \& Dollard, J. (1941). Social Learning and Imitation. New Haven: Yale University Press.

Mulitalo-Lauta, P.T.M.T. (2000). FaaSāmoa and social work within the New Zealand context. Palmerston North, NZ: Dunmore Press.

Pardini, D.A., Waller, R., \& Hawes, S.W. (2015). Familial influences on the development of serious conduct problems and delinquency. (in) J. Morizot \& L. Kazemian (Ed.). The development of criminal and antisocial behaviour: Theory, research and practical applications. New York: Springer. (pp. 201-220).

Parsons, T. (1951). The Social System. Glencoe: The Free Press.

Parsons, T. (1959). The school class as a social system: Some of its functions in American society. Harvard Educational Review, 29, 297-318.

Phinney, J.S., \& Chavira, V. (1995). Parental ethnic socialization and adolescent coping with problems related to ethnicity. Journal of Research on Adolescent, 5 (1), 31-53.

Phinney, J.S., \& Rotheram, M.J. (1987). Children's ethnic socialization. New York: Lawrence Erlbaum Associates, Inc.

Plummer, K. (1983). Documents of Life: An introduction to the problems and literature of a humanistic method. London: Allen and Unwin. 
Plummer, K. (1995). Life story research. (in) J. Smith, R. Harre \& L. Van Langhove (Eds.). Rethinking methods in Psychology. London: Sage. (pp. 50-64).

Plummer, K. (2001). Documents of Life 2: An invitation to a critical humanism. London: Sage.

Potter, R.B. (2005). Young, gifted and back: second-generation transnational return migrants to the Caribbean. Progress in Development Studies, 5, 213-36.

Potter, R.B., Conway, D. \& Phillips, J. (2005). The experience of return migration: Caribbean perspectives. Aldershot: Ashgate.

Potter, R.B., Conway, D. \& St. Bernard, G. (2009). Transnationalism personified: Young returning Trinidadians in their own words. Journal of Economic and Social Geography, 100 (1), 101-113.

Roberts, B. (2002). Biographical Research. Buckingham: Open University Press.

Rosenthal, G. (1993). Reconstruction of life stories: Principles of selection in generating stories for narrative biographical interviews. (in) R. Josselson, \& A. Leiblich (Eds.). The narrative study of lives: Volume 1. Newbury Park, CA: Sage. (pp. 59-91)

Ryman, G.W. \& Bernard, H.R. (2003). Techniques to identify themes. Field Methods, 15 (1), 85-109.

Santrock, J.W. (Eds.) (2008). A Topical Approach to Lifespan Development. New York: McGraw-Hill.

Sheldon, S. (1980). Symbolic Interactionism: A social structural version. Menlo Park, CA: Benjamin/Cummings.

Sheldon, S. \& Vryan, K.D. (2003). The Symbolic Interactionist Frame. (in) J. Delamater (Ed.). Handbook of Social Psychology. New York: Kluwer Academic/Plenum Publishers. (pp. 3-28).

Thomas-Hope, E.M. (1985). Return migration and its implications for Caribbean development. (in) R.A. Pastor (Ed.). Migration and Development in the Caribbean: The unexpected connection. Boulder, Colorado: Westview Press. (pp. 157-177).

Umaña-Taylor, A.J. \& Fine, M.A. (2004). Examining ethnic identity among Mexican-origin adolescents living in the United States. Hispanic Journal of Behavioral Sciences, 26, $36-59$.

Zayas, L.H. \& Solari, F. (1994). Early childhood socialization in Hispanic families: Context, cultures, and practice implications. Professional Psychology: Research and Practice, 25 (3), 200-206.

Moses Ma'alo Faleolo is a NZ-born Sāmoan. His father, Leaula Mose, is from Falelima; holds an orator title from Saleaula village, both of which are in Savai'i, Sāmoa and is a church elder and lay preacher. His mother, Pepe, is from the village of Leusoali'i, Upolu, Sāmoa, and is a Justice of the Peace, Lay Advocate and early childhood teacher. Moses practised social work for over 10 years before becoming an academic. He worked with youth offenders and young people with behavioural issues in both government and community organisations. $\mathrm{He}$ is currently a registered social worker, lecturer in social work, and oversees the Bachelor of Social Work program at Massey University. He believes that effective lecturers need to have worked on the frontline to bring alive the theoretical and clinical aspects of social and community work practice in teaching. He has published nationally and internationally in the area of social work education. His $\mathrm{PhD}$ entitled, "Hard-Hard-Solid: Life histories of Sāmoans in Bloods Youth Gangs in New Zealand" is the first of its kind and presents the results of in-depth analysis of findings from 18 months of observation, engagement and interviews and with this hard-to-reach-population. 

